\title{
EKSISTENSI MANUSIA \\ DALAM MANAJEMEN PENDIDIKAN ISLAM \\ (Tinjauan Kritis dari Segi Fungsi Penggerakan/Motivating)
}

\author{
Hadi Kusuma Ningrat \\ Dosen Pendidikan IPA Biologi FITK IAIN Mataram
}

\begin{abstract}
Abstrak
Manajemen organisasi akan terlaksana dengan baik jika tersedia sumberdaya organisasi yang dibutuhkan, yang dikenal dengan singkatan $7 \mathrm{M}$ (man, money, machines, material, marketing, methods, dan minutes). Berdasarkan sudut pandang fungsi penggerakan (motivating) dalam manajemen (khususnya manajemen pendidikan Islam) bahwa asset yang maha penting di antara sumber daya organisasi tersebut adalah sumber daya manusia (man). Keberadaannya sebagai penggerak utama sumber daya organisasi lainnya. Hal tersebut akan terwujud, apabila tujuan/kepentingan organisasi dan kepentingan anggota organisasi sinergis; saling menguntungkan. Untuk tujuan tersebut, maka pimpinan organisasi perlu mengetahui dan memahami karakteristik anggota organisasinya. Lebih lanjut pembahasan tentang eksistensi manusia dari segi fungsi penggerakan (motivating) dalam manajemen pendidikan Islam akan diuraikan di bawah ini.
\end{abstract}

Kata Kunci: eksistensi, manusia, manajemen pendidikan Islam, dan fungsi penggerakan (motivating) 


\section{PENDAHULUAN}

Dalam dunia manajemen/organisasi, manusia (anggota organisasi/staf) merupakan unsur terpenting. Kenyataan tersebut bukan saja karena manusia merupakan mahkota ciptaan Tuhan. Bukan pula karena manusia mempunyai rasio, yang membedakannya dari makhluk lainya. Manusia sebagai unsur terpenting dalam manajemen/organisasi karena unsur-unsur lainnya yang dimiliki oleh suatu organisasi-seperti modal usaha, bahan baku, mesin-mesin, metode kerja, waktu, dan kekayaan lainnya-hanya dapat memberi manfaat bagi organisasi jika manusia mendayagunakannya. Dengan kata lain, manusia adalah sebagai perencana, pelaksana, pengendali, pengontrol, pengevaluasi, dan pengembang segala program organisasi. Karenanya, intensitas keberhasilan organisasi tergantung pada kreativitas manusia yang ada dalam organisasi itu sendiri. Sebagaimana pendapat Sudjana (2004:145) bahwa:

...faktor manusia merupakan unsur terpenting dalam manajemen, termasuk dalam organisasi. Organisasi pada dasarnya adalah suatu wahana yang efektivitas kegiatannya akan sangat ditentukan oleh unsur manusia yang menyandang tugas-tugas organisasi atau sebagai pelaksana kegiatan organisasi. Unsur-unsur lain dalam organisasi seperti fasilitas, alat-alat, waktu, metode, dan teknik kegiatan, didayagunakan secara optimal oleh manusia yang berada dalam organisasi atau orang-orang yang berkaitan dengan organisasi. Dengan perkataan lain, bahwa kemantapan kegiatan dan keberhasilan suatu organisasi sering tidak ditentukan oleh lengkapnya unsur non-manusia dan struktur organisasi, melainkan akan sangat ditentukan oleh unsur sumber daya manusia yang terlibat dalam organisasi itu sendiri.

Hal senada juga ditegaskan lagi oleh Hasibuan (2005:10) bahwa manusia akan selalu berperan aktif dan dominan dalam setiap kegiatan organisasi, karena manusia menjadi perencana, pelaku, dan penentu terwujudnya tujuan organisasi. Tujuan organisasi tidak mungkin terwujud tanpa peran aktif manusia, meskipun alat-alat yang dimiliki perusahaan begitu canggihnya.

56 BIOTA: Jurnal Tadris IPA Biologi FITK IAIN Mataram 
Alat-alat canggih yang dimiliki perusahaan tidak ada manfaatnya bagi perusahaan, jika peran aktif karyawan tidak diikutsertakan.

Lebih lanjut dinyatakan oleh Hasibuan (2005:10) bahwa menempatkan manajemen sumber daya manusia sebagai salah satu fungsi terpenting dalam manajemen/organisasi memberikan pengakuan besar bahwa unsur manusia merupakan unsur paling dominan penentu keberhasilan pencapaian tujuan organisasi. Karena itu, keberadaan manusia dalam organisasi merupakan asset (kekayaan) utama yang harus dipelihara dan dikembangkan dengan baik. Keberadaanya menjadi roh bagi dinamika organisasi. Berhasil tidaknya pecapaian tujuan organisasi tergantung pada kiprah manusia di dalam organisasi itu sendiri.

Fathoni (2006:12-13) juga secara lebih luas memberikan argumentasi bahwa di dalam organisasi setidaknya ada 4 (empat) asumsi dasar posisi startegis manusia, yaitu:

1. Manusia adalah pelaksana organisasi yang mempunyai kewenangan untuk menetapkan, mengendalikan, dan mengarahkan pencapaian tujuan organisasi;

2. Manusia adalah pelaku yang memimpin usaha agar proses pencapaian tujuan yang dilaksanakan bisa tercapai sesuai dengan rencana

3. Manusia adalah pelaku yang memenuhi syarat tertentu, diangkat langsung melaksanakan pekerjaan sesuai dengan bidang tugasnya masing-masing atau jabatan yang dipegangnya.

4. Manusia adalah makhluk yang mempunyai kesadaran diri. Dengan kesadaran diri tersebut, ia akan bergerak sendiri walaupun tanpa dikendalikan atau disuruh (bukan karena terpaksa).

Terkait dengan hal di atas, lembaga pendidikan Islam sebagai sebuah organisasi juga tidak menapikan peran manusia dalam pencapaian tujuan pendidikannya. Manusia yang dimaksud di sini adalah pendidik dan tenaga kependidikan (staf). Intensitas peranan mereka menentukan kualitas/keberhasilan pencapain tujuan pendidikan yang telah ditetapkan. Bahkan dapat dikatakan bahwa kreativitas staf sebagai ruh dalam pengembangan lembaga 
pendidikan. Sehingga tidak salah apabila Daulay (2006:59) dan Suwarno (2006:33) mengatakan bahwa staf dalam lembaga pendidikan dapat disebut sebagai the man behind the gun. Bukan senjatanya yang menentukan, tetapi manusia yang memainkan senjata tersebut. Mereka adalah komponen pendidikan yang ketiadaan mereka membuat kediadaan proses pencapaian tujuan pendidikan.

Selanjutnya, menurut Mochtar (1986:182) dan Jawahir (1983: 111) bahwa apabila ditilik dalam doktrin agama, maka pentingnya posisi manusia dalam manajemen/organisasi tidak terlepas dari kenyataan bahwa manusia adalah sebagai khalifatullah di dunia ini. Dalam fungsinya sebagai khalifatullah, manusia dengan segala kompetensi yang dimilikinya diberikan kepercayaan oleh Allah SWT untuk mengelola/mengatur dirinya dan potensi alam yang tersedia dengan sebaik-baiknya untuk kesejahteraan hidupnya. Di dalam Al-Qur'an terdapat beberapa ayat yang menegaskan bahwa keberadaan manusia di dunia ini sebagai khalifatullah, di antaranya:

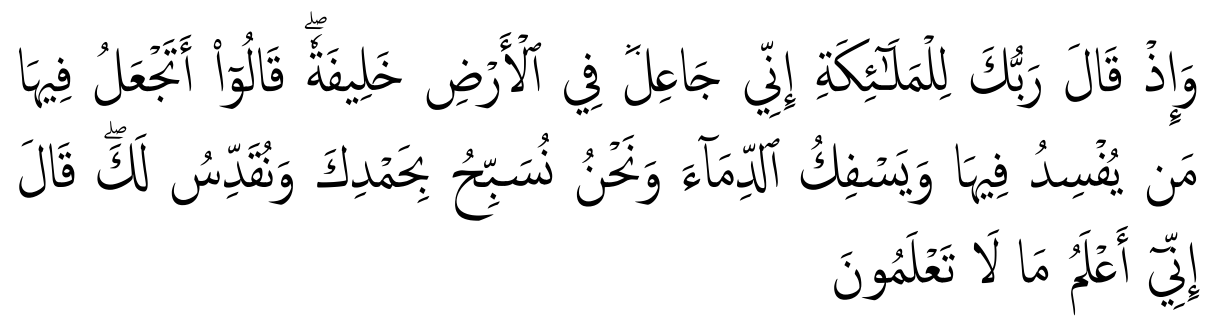

Artinya, "Ingatlah ketika Tuhanmu berfirman kepada Para Malaikat: "Sesungguhnya aku hendak menjadikan seorang khalifah di muka bumi."..." (QS. Al-Baqarah: 30) (Depag. RI, 2005:5).

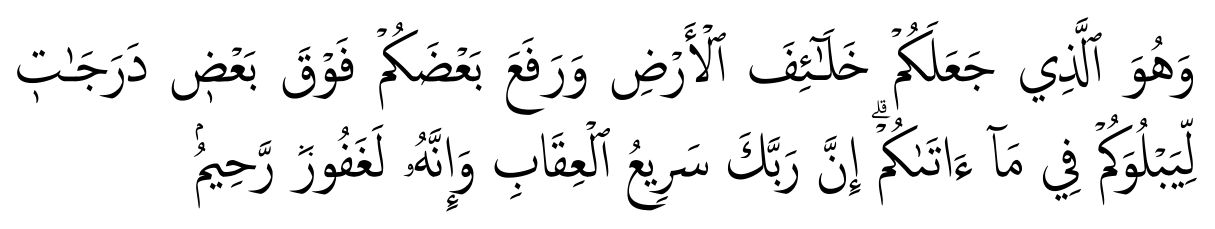

58 BIOTA: Jurnal Tadris IPA Biologi FITK IAIN Mataram 
Artinya, "Dan Dialah yang menjadikan kamu penguasa-penguasa di bumi dan dia meninggikan sebahagian kamu atas sebahagian (yang lain) beberapa derajat, untuk mengujimu tentang apa yang diberikan-Nya kepadamu. Sesungguhnya Tuhanmu amat cepat siksaan-Nya dan Sesungguhnya dia Maha Pengampun lagi Maha Penyayang”. (QS. Al-An'am: 165) (Depag. RI, 2005:150).

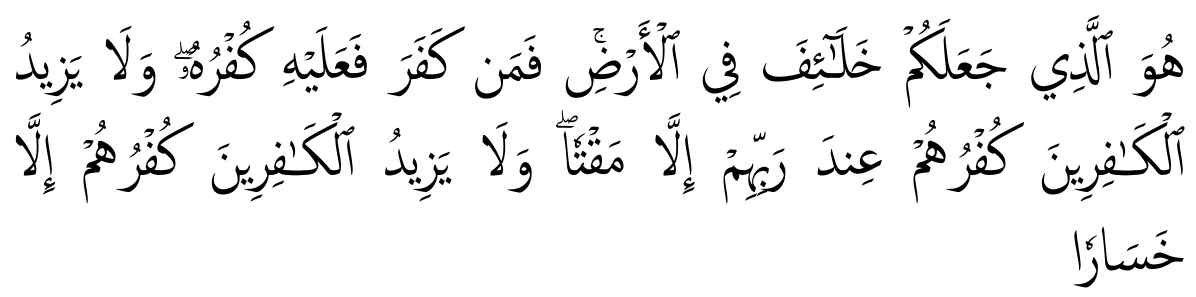

Artinya, "Dialah yang menjadikan kamu khalifah-khalifah di muka bumi ...”. (QS. Faathir: 39) (Depag. RI, 2005:439)

\section{PEMBAHASAN}

Eksistensi Manusia dalam Organisasi Ditinjau dari Segi Fungsi Penggerakan dalam Manajemen Pendidikan Islam

Telah diutarakan di atas, bahwa eksistensi/keberadaan manusia dalam manajemen/organisasi sangat penting. Namun perlu diketahui bahwa dalam kenyataanya bahwa unsur manusia dalam organisasi di satu pihak akan dapat mendukung tugas organisasi dan fungsi pengelolaannya, sedangkan di pihak lain dapat pula menghambat kelancaran tugas organisasi dan pengelolaannya. Menurut Siagian (2005:105) bahwa hal tersebut dapat terjadi apabila manusia merongrong organisasi demi kepentingan pribadinya, mogok kerja, atau manusia tidak memiliki motivasi kerja. Jika hal tersebut terjadi, maka manusia itu merupakan masalah besar yang sukar dipecahkan oleh organisasi. Karenanya, tidak berlebihan kiranya apabila ditekankan di sini bahwa pelaksanaan program organisasi pada hakikatnya harus bertitik tolak dari pentingnya manusia itu sebagai unsur perangsang dan mengurangi kemungkinan 
timbulnya kerugian bagi organisasi dari perilaku jelek yang dibawa manusia ke dalam organisasi.

Adanya dua kenyataan tersebut dilatarbelakangi oleh faktor pendorong dan faktor penghambat yang timbul dari dalam dan dari luar diri manusia itu sendiri. Faktor pendorong dan penghambat ini dapat dianalisis dengan menggunakan formula SWOT (strength, weakness, opportunity, and threat) atau analisis tentang kekuatan, kelemahan, peluang atau kesempatan, dan tantangan. Dalam pengelolaannya, pimpinan organisasi sudah seharusnya mempertim-bangkan faktor kekuatan, kelemahan, peluang atau kesempatan, dan tantangan. Faktor kekuatan hendaknya dipertahankan dan bahkan dikembangkan, supaya pihak yang dipimpinnya melaksanakan tugas dan kegiatannya sebagaimana harus mereka lakukan dengan sebaik-baiknya. Pimpinan organisasi pun harus mengurangi faktor kelemahan sekecil mungkin bahkan berupaya untuk menghilangkannya, sehingga tidak mengganggu pihak yang dipimpin dalam melaksanakan tugas dan kegiatan organisasi. Peluang atau kesempatan perlu dikaji oleh pimpinan organisasi, sehingga unsur manusia dan organisasi dapat berkiprah dengan memanfaatkan peluang-peluang yang ada di luar organisasi dalam mencapai tujuan organisasi. Demikian pula tantangan atau ancaman dari luar organisasi perlu dipahami, sehingga pimpinan dapat menghindari dampaknya sekecil mungkin bagi organisasi. Oleh sebab itu, pimpinan organisasi perlu memanfaatkan faktor kekuatan, kelemahan, peluang, dan tantangan menjadi pemacu kegiatan pihak yang dipimpinnya dan mengatasi faktor kelemahan sehingga tidak menimbulkan dampak negatif bagi kegiatan organisasi. Sing-katnya, kekuatan dan kelemahan terdapat dalam organisasi, sedangkan peluang dan tantangan datang dari luar organisasi (Sudjana, 2004:146-146).

Upaya tersebut akan dapat dilaksanakan apabila pihak yang memimpin suatu organisasi memahami dan mampu melaksanakan fungsi penggerakan. Fungsi penggerakan tidak lain merupakan salah satu bagian dari fungsi-fungsi manajerial dalam manajemen/organisasi. Keberadaannya sebagai fungsi organik dalam kegiatan manajemen/organisasi. Fungsi organik adalah

60 BIOTA: Jurnal Tadris IPA Biologi FITK IAIN Mataram 
semua fungsi yang mutlak harus dijalankan dalam kegiatan manajemen/organisasi. Ketidakmampuan untuk menjalankan fungsi-fungsi itu akan mengakibatkan-lambat atau cepat-matinya organisasi. Fungsi organik yang dimaksud adalah fungsi perencanaan, fungsi pengorganisasian, fungsi penggerakan, fungsi pengendalian, dan fungsi penilaian. Pembagian macam-macam fungsi organik manajerial tersebut tidak mutlak, sebab masingmasing ahli mempunyai pendapat yang berbeda-beda (Siagian, 2005: 83).

Terkait dengan hal di atas, Sudjana (2004:53) menjelaskan bahwa sebagai salah satu bagian dari fungsi-fungsi manajerial, maka posisi fungsi penggerakan dalam rangkaian fungsi manajemen/organisasi apabila diilustrasikan dalam sebuah gambar akan tampak sebagai berikut;

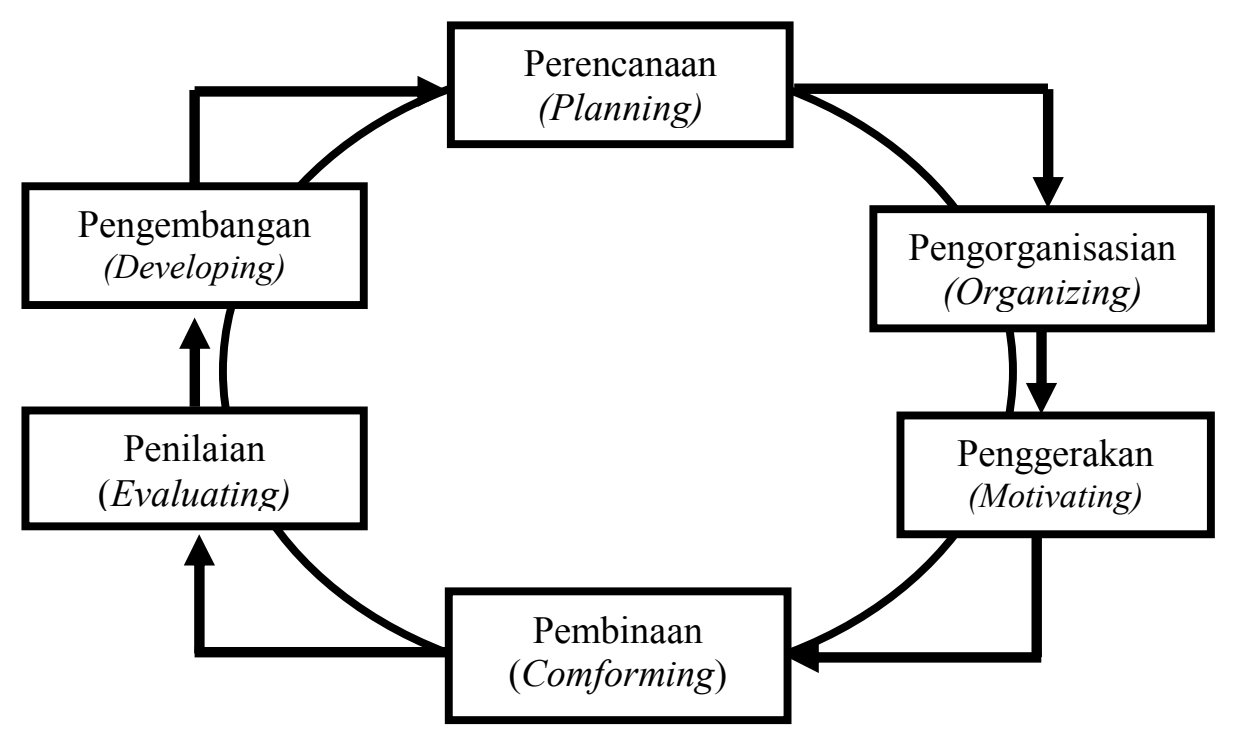

Gambar 1

Rangkaian Fungsi Manajerial 
Secara terminologis, sebagaimana pendapat Siagian (2005:95) bahwa "Penggerakan dapat didefinisikan sebagai keseluruhan usaha, cara, teknik, dan metode untuk mendorong para anggota organisasi agar mau ikhlas bekerja dengan sebaik mungkin demi tercapainya tujuan organisasi dengan efisian, efektif, dan ekonomis". Ranupandojo (1996:101), Bafadal (2004:92), dan Sukarna (2000:82) juga berpendapat bahwa penggerakan adalah segala usaha pimpinan organisasi dalam mendorong anggota organisasi agar mau, mampu, dan ikhlas bekerja sebaik mungkin untuk mencapai tujuan organisasi.

Senada dengan pendapat-pendapat para ahli di atas, Sudjana (2004:146) juga memberikan batasan bahwa;

Penggerakan (motivating) dapat diartikan sebagai upaya pimpinan untuk menggerakkan (memotivasi) seseorang atau kelompok orang yang dipimpin dengan menumbuhkan dorongan atau motive dalam diri orangorang yang dipimpin untuk melakukan tugas atau kegiatan yang diberikan kepadanya sesuai dengan rencana dalam rangka mencapai tujuan organisasi.

Berdasarkan batasan-batasan di atas, dapat dikemukakan bahwa fungsi penggerakan mempersoalkan bagaimana caranya mendorong gairah kerja anggota organisasi, agar mereka mau bekerja keras dengan memberikan segenap kemampuan dan keterampilannya untuk mewujudkan tujuan organisasi. Organisasi pada dasarnya bukan saja mengharapkan anggota organisasi yang "mampu, cakap dan terampil", tetapi yang terpenting adalah anggota organisasi yang mau bekerja giat dan berkeinginan untuk mencapai hasil kerja yang optimal. Kemam-puan, kecakapan dan keterampilan anggota organisasi tidak ada artinya bagi organisasi, apabila anggota organisasi tidak mau bekerja keras dengan memper-gunakan kemampuan, kecakapan dan keterampilan yang dimilikinya.

Penggerakan juga tidak lain merupakan usaha pimpinan organisasi dalam bagaimana mengerti kondisi anggota organisasinya (apa yang dirasakan, apa yang dimiliki, apa yang dipahami, dan apa yang diharapkan). Dengan kata lain, dalam

62 BIOTA: Jurnal Tadris IPA Biologi FITK IAIN Mataram 
fungsi penggerakan pimpinan organisasi akan berusaha menjadi pendengar atau pelayan yang baik terhadap anggota organisasinya. Dengan cara tersebut, pimpinan organisasi tahu bagaimana menyikapi anggota organisasinya dan memberdayakannya sesuai dengan dengan keadaan masingmasing individu anggota organisasi agar produktif dan berguna bagi kemajuan organisasi. Singkatnya, fungsi penggerakan adalah fungsi di mana asas keseimbangan organisasi menjadi orientasi utamanya, karena keseimbangan merupakan kunci utama organisasi agar dapat berkembang secara produktif dan wajar. Pimpinan organisasi tidak hanya mengedepankan kemauan atau tuntutan organisasi semata, tetapi juga memperhatikan keadaan anggota organisasi. Tujuannya agar terwujud keseimbangan antara tuntutan organisasi dan kebutuhan anggota organisasi.

Dengan demikian, dapat dipahami bahwa fungsi penggerakan adalah seni atau alat bagi pimpinan organisasi dalam mempengaruhi, membimbing, mengarahkan, dan memberikan dorongan kepada anggota organisasi agar energi-energi positif dalam diri anggota organisasi tersalurkan dalam kerja optimal demi tercapainya tujuan organisasi. Fungsi penggerakan sebagai alat dalam pencapaian tujuan organisasi, secara tidak langsung menjadikan dirinya sebagai fungsi manajerial yang terpenting dan paling dominan dalam manajemen/organisasi. Tentunya, apabila fungsi ini diterapkan, maka proses manajemen dalam merealisasi tujuan dimulai (Hasibuan, 2006:183). Dengan kata lain, memberikan pengakuan besar akan strategisnya posisi manusia dalam manajemen/organisasi, berarti memberi-kan pengakuan akan tidak kalah pentingnya fungsi penggerakan dalam manajemen/organisasi. Apabila manusia dipandang sebagai obyek yang digerak-kan, maka fungsi penggerakan adalah alat untuk menggerakkan manusia itu sendiri. Fungsi penggerakan ibarat kunci starter mobil, artinya mobil akan dapat berjalan jika kunci staternya telah melaksanakan fungsinya.

Pada tataran praktis, pelaksanaan fungsi penggerakan dipandang sebagai fungsi manajerial yang kompleks dan tersulit sebab pimpinan organisasi harus berhadapan dengan manusia sebagai makhluk penuh misteri dengan segala karakteristik yang 
dimiliki. Oleh karenanya, pelaksanaan fungsi penggerakan tidak akan memberikan hasil apapun apabila pimpinan memperlakukan sama tiap individu anggota organisasi. Dengan kata lain, pelaksanaan fungsi penggerakan tidak bisa hanya dengan mengandalkan satu teknik. Varian teknik penggerakan harus tersedia sebagai alternatif dalam menghadapi tiap individu anggota organisasi yang berbeda (Mulyasa, 2003:143). Penggerakan anggota organisasi dapat melalui pembinaan disiplin, memberikan tindakan punitif bagi anggota organisasi yang melangggar, pemberian tekanan, pemberian rewards, mendelegasikan tugas/ wewenang yang lebih besar, promosi jabatan, penciptaan iklim organisasi yang kondusif, penciptaan suasana kerja yang aman dan menyenangkan, penciptaan persaingan kerja dalam organisasi, tugas belajar, penciptaan suasana kekeluargaan dan kebersamaan dalam lingkungan kerja, memberikan peluang pengembangan kompetensi, melibatkan anggota organisasai dalam segenap program organisasi, dan lain sebagainya. Teknik yang beraneka ragam tersebut akan efektif terlaksana apabila sesuai kondisi lingkungan di mana penggarakan itu dilaksanakan.

Dalam sejarah perkembangan manajemen/organisasi, permasalahan bagaimana menggerakkan anggota organisasi menjadi perbincangan yang alot. Para ahli mempunyai pendapat yang berbeda-beda dan masing-masing pendapat disertai dengan argumen yang menurut mereka paling tepat. Memang masuk akal, sebab pendapat yang ditawarkan oleh para ahli terkait teknik penggerakan berasal dari apa yang ditemukan dalam penelitian lapangan yang pernah dilakukannya. Perbedaan karakteristik lokasi tempat penelitian, perbedaan obyek atau orang digerakkan, perbedaan pendekatan yang digunakan dalam penelitian, dan perbedaan waktu diadakannya penelitian turut memberikan perbedaan hasil penelitian para ahli. Teknik-teknik penggerakan yang ditawarkan tentunya tidak akan bisa diterapkan secara serta merta di setiap organisasi. Sekali lagi, seperti yang dikemukakan di atas bahwa penerapan teknik penggerakan akan efektif apabila melihat kondisi lingkungan di mana penggerakan itu dilaksanakan.

64 BIOTA: Jurnal Tadris IPA Biologi FITK IAIN Mataram 
Berdasarkan hasil penelitian para ahli, ditemukan beberapa teknik penggerakan yang dapat digunakan untuk mendorong anggota organisasi agar mau dan ikhlas bekerja sebaik mungkin. Teknik-teknik tersebut setidaknya dapat diambil dari mempelajari periode perkembangan sifat dan hubungan kerja manusia dalam organisasi yang terbagi menjadi tiga periode, yaitu periode pendekatan manajemen klasik, periode pendekatan hubungan manusiawi, dan periode pendekatan sumber daya manusia.

\section{1) Periode Pendekatan Manajemen Klasik}

Pada periode pendekatan manajemen klasik manusia dipandang dan diperlakukan layaknya faktor produksi lainnya seperti faktor gedung, modal, mesin, dan bahan baku. Implikasi dari sudut pandang tersebut adalah adanya hubungan yang kaku antara pihak organisasi (pimpinan organisasi) dengan anggota organisasi. Hubungan mereka layaknya antara juragan dan anak buah. Pelaksanaan fungsi penggerakan dengan gaya otokratik melalui tindakan-tindakan punitif bagi anggota organisasi yang kinerjanya tidak sesuai dengan harapan organisasi (Ranupandojo, 1996:104). Di samping kenyataan tersebut, pada periode pendekatan klasik motivasi kerja manusia dipandang dari sudut pemenuhan kebutuhan fisiologis semata. Oleh karena itu, memperhatikan tingkat kesejahteraan mereka menjadi cara yang ampuh apabila pimpinan organisasi ingin mening-katkan produktivitas kerjanya. Dari kenyataan tersebut lahirlah teorinya F.W. Taylor yang mengemukakan bahwa kebutuhan manusia hanyalah kebutuhan tunggal, yaitu kebutuhan fisiologis saja. Oleh karena itu, peningkatan tingkat kesejateraan anggota organisasi menjadi teknik pengge-rakan yang efektif bagi mereka (Amirullah dan Rindyah Hanafi, 2002:148).

2) Periode Pendekatan Hubungan Manusiawi

Periode pendekatan hubungan manusiawi adalah peralihan dari periode pendekatan manajemen klasik. Pada periode ini pimpinan organisasi tidak lagi menggunakan teknik 
penggerakan yang biasanya dipakai pada pendekatan manajemen klasik. Pada dasarnya, pendekatan hubungan manusiawi memandang motivasi kerja manusia dari perspektif manusia sebagai insan sosial yang selalu membutuhkan interaksi harmonis dengan sesamanya. Lahirnya paradigma tersebut dilatarbelakangi oleh adanya kejenuhan anggota organisasi akan kondisi lingkungan kerja saat itu sebagai dampak dari pendekatan manajemen klasik. Orang yang pertama kali memperkenalkan pendekatan ini adalah Elton Mayo. Melalui penelitiannya yang berjudul The Howthorne Studies dihasilkan teori bahwa produktivitas kerja manusia akan didapatkan apabila pimpinan organisasi memperlakukan anggota organisasi dengan baik dan wajar sesuai dengan fitrah kemanu-siaannya. Oleh karena itu, menekankan perlakuan manusiawi merupakan alat efektif untuk menggerakkan anggota organisasi (Kennedy, 1999:8384). Secara detail berikut kesimpulan hasil penelitian Elton Mayo: (a) masalah manusia hanya akan dapat diselesaikan secara manusiawi dan menggunakan data, informasi, dan alatalat kemanusiaan pula; (b) moral dan semangat kerja lebih besar peranan dan pengaruhnya untuk meningkatkan produktivitas kerja anggota organisasi daripada kompensasi. Moral adalah suatu keadaan yang berhubungan erat dengan kondisi mental seseorang; dan (c) perlakuan yang baik dan wajar terhadap anggota organisasi lebih besar pengaruhnya untuk peningkatan produktivitas kerja daripada tingkat kompensasi yang besar, walaupun kompensasi juga penting (Hasibuan, 2006:185).

3) Periode Pendekatan Sumber Daya Manusia

Secara historis, pendekatan sumber daya manusia juga merupakan peralihan dari periode pendekatan hubungan manusiawi. Pendekatan ini lahir sebagai bentuk protes terhadap dua pendekatan sebelumnya. Salah seorang ahli yang mempelopori lahirnya pendekatan ini adalah Douglas McGregor. Melalui penelitiannya ditemukan teori bahwa manusia masuk pada tipe Y. Karenanya, manusia tidak secara otomatis melihat pekerjaan sebagai sesuatu yang tidak

66 BIOTA: Jurnal Tadris IPA Biologi FITK IAIN Mataram 
dikehendaki, melainkan justru pekerjaan sebagai sarana pengem-bangan diri untuk mencari prestasi. Terdapat tiga prinsip utama dalam memandang prilaku manusia dalam organisasi yaitu: (a) manusia cenderung memperoleh kepuasan dari prestasi yang baik; (b) anggota organisasi berprestasi bukan karena insentif dan pengakuan sosial; (c) motivasi kerja menurut pendekatan sumber daya manusia lebih disebabkan karena adanya kesadaran untuk meraih prestasi kerja itu sendiri. Dengan mengacu pada tiga prinsip tersebut, bagi pimpinan organisasi yang ingin meningkatkan kinerja anggota organisasinya media penggerakan yang tepat digunakan adalah memberikan kesempatan bagi anggota organisasi untuk pengembangan diri. Langkah tersebut dapat dilakukan melalui penciptaan kompetisi kerja dalam organisasi, pendelegasian tugas atau wewenang yang lebih besar, dan mengikutsertakan anggota organisasi dalam segenap program organisasi (Amirullah dan Rindyah Hanafi, 2002:149).

Sampai di sini, pertanyaan yang muncul adalah "Bagaimana eksistensi dan pelaksanaan fungsi penggerakan di lembaga pendidikan Islam?". Lembaga pendidikan Islam yang juga merupakan sebuah organisasi tentu saja tidak berbeda pandangannya dengan organisasi lainnya tentang eksistensi dan pelaksanaan fungsi penggerakan. Yang berbeda, jika selama ini fungsi penggerakan lebih banyak diperbincangkan dalam manajemen perusahaan/organisasi umum, sedangkan lembaga pendidikan Islam adalah organisasi sosial nirlaba yang bercirikan keagamaan. Perbincangan dan pelaksanaan fungsi penggerakan tidak terjebak pada predikat yang disandang oleh tiap organisasi, tetapi lebih pada bagaimana sebuah organisasi memandang eksistensi manusia (anggota organisasi) yang dimiliki bagi pencapaian tujuan organisasi. Oleh karena itu, apabila direlevansikan dengan definisi fungsi penggerakan di atas maka fungsi penggerakan di lembaga pendidikan Islam dapat diartikan sebagai keseluruhan usaha, teknik, cara, dan metode yang dilakukan oleh pimpinan lembaga pendidikan Islam untuk memberikan dorongan kepada staf yang dimilikinya agar mau dan 
ikhlas bekerja dengan sebaik mungkin demi tercapainya tujuan pendidikan dengan efisian, efektif, dan ekonomis. Kalau boleh ditambah, agar tidak menghilangkan nilai keislamannnya maka fungsi penggerakan di lembaga pendidikan Islam dapat diartikan sebagai usaha, teknik, cara, dan metode yang dilakukan oleh pimpinan lembaga pendidikan Islam untuk memberikan dorongan kepada staf yang dimilikinya agar mau dan ikhlas bekerja dengan sebaik mungkin demi tercapainya tujuan pendidikan dengan efisien, efektif, dan ekonomis serta mampu membuat staf memandang pekerjaan bukan sebagai beban, melainkan sebagai sarana pengembangan diri dan sarana ibadah kepada Allah.

Terkait dengan hal di atas, Suprayogo (2006:3), Mochtar (1986:180), dan Jawahir (1983:112), menjelaskan bahwa tidak ada satu pekerjaan yang dilakukan oleh manusia yang paling mulia atau tinggi nilainya, kecuali pekerjaan tersebut diniatkan sebagai sarana ibadah atau mendekatkan diri kepada Allah SWT. Oleh karena itu, setiap manusia (umat Islam) harus mampu menjadikan segala tempat yang disinggahinya laksana masjid, dalam artian bahwa seluruh pekerjaan yang dilakukannya atas nama ibadah kepada Allah SWT. Allah SWT harus menjadi tujuan dan/atau motivasi tertinggi dari segenap aktivitas manusia. Ketika manusia (umat Islam) meniatkan segenap kegiatannya untuk mendapatkan ridha Allah, maka Allah akan senantiasa mencurahkan rahmat-Nya kepada manusia tersebut.

Hal di atas perlu dilakukan, sebab hal itu sebagai konsekuensi logis bahwa manusia adalah hamba Allah yang keberadaannya di dunia ini untuk menyembah-Nya. Sebagaimana yang digariskan Allah SWT dalam Al-Qur'an surat Adz-Dzariyat ayat 56. Ayat yang dimaksud di sini adalah yang artinya:

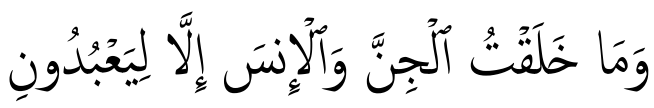

Artinya, "Dan Aku tidak menciptakan jin dan manusia melainkan supaya mereka mengabdi kepada-Ku" (QS. Adz-Dzariyat: 56) (Depag. RI, 2005:532).

68 BIOTA: Jurnal Tadris IPA Biologi FITK IAIN Mataram 
Pekerjaan yang diniatkan sebagai sarana ibadah mempersyaratkan mobilisasi dan optimalisasi pemberdayaan segenap potensi di jalan Allah untuk kebaikan setiap orang. Pekerjaan yang diniatkan sebagai sarana ibadah juga menuntut kesabaran dan kontinuitas kerja, bahkan menuntut tingkat kesabaran ekstra yang mampu mengungguli kesabaran para pesaing. Semua itu didukung dengan ketekunan untuk murabathah, yakni pantang meninggalkan pekerjaan sebelum selesai. Sebagaimana diajarkan dalam firman Allah SWT dalam alQur'an surat al-Imran, yaitu yang artinya:

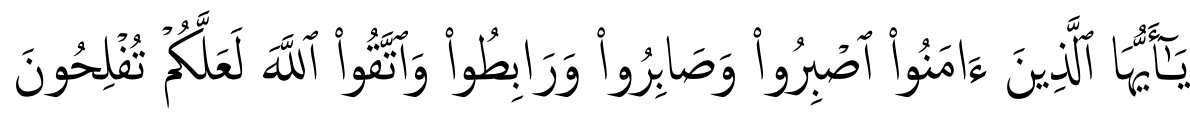

Artinya, "Hai orang-orang yang beriman, Bersabarlah kamu dan kuatkanlah kesabaranmu dan tetaplah bersiap siaga (di perbatasan negerimu) dan bertakwalah kepada Allah, supaya kamu beruntung". (QS. Al-Imran: 200) (Depag. RI, 2005:76)

Di samping itu juga, pekerjaan yang diniatkan sebagai sarana ibadah menolak setiap bentuk ketidakcermatan dalam memanage waktu yang begitu berharga; ketidakprofesionalan dalam mengelola sumber daya yang demikian mahal. Dengan tegas pula, ia menolak setiap perasaan dan sikap lemah, malas dan kurang serius, mengandalkan pada kemampuan orang lain untuk menyelesaikan pekerjaan, lebih-lebih mencatut prestasi orang lain sebagai hasil karyanya. Singkatnya, dengan bekerja yang diniatkan untuk ibadah, setiap muslim akan mampu mengukir prestasi dengan penuh kegairahan, kemudian secara pasti akan mengembalikan 'izzah atau harga dirinya, sehingga disegani oleh umat lain. Sebab, kemuliaan dan gensi itu adalah milik Allah, rasul-Nya, serta orang-orang beriman.

Apabila ditelisik lebih dalam, perbincangan tentang fungsi penggerakan di lembaga pendidikan Islam mungkin saja lebih menarik-atau bahkan sangat menarik-dibanding fungsi penggerakan dalam organisasi-organisasi lainnya, sebab lembaga 
pendidikan Islam (terutama yang swasta) sampai saat ini menurut Usa (2000:11) dan Soebahar (2002:149-150) bahwa oleh masyarakat luas masih dipandang sebagai lembaga pendidikan kelas dua yang secara kualitas masih kalah saing dengan lembaga pendidikan umum.

Hal tersebut berarti perbincangan dan pelaksanaan fungsi penggerakan di lembaga pendidikan Islam dimaksudkan agar bagaimana fungsi penggerakan dapat memberikan andil dalam rangka membebaskan lembaga pendidikan Islam dari ketertinggalannya. Yang dimaksud di sini adalah bagaimana pimpinan lembaga pendidikan Islam memberdayakan stafnya secara maksimal agar lembaga pendidikan Islam mampu mencapai tujuan pendidikan sesuai dengan harapan semua pihak.

Menyadari kenyataan bahwa lembaga pendidikan Islam sebagai lembaga pendidikan kelas dua yang secara kualitas masih kalah saing dengan lembaga pendidikan umum, maka dapat dikatakan bahwa pelaksanaan fungsi penggerakan akan sangat sulit. Hal ini karena pelaksanaan fungsi penggerakan diharapkan akan dapat menjadi solusi bagi kondisi yang dialami lembaga pendidikan Islam, minimal dapat memperbaiki kinerja staf agar nantinya mereka mau dan mampu menciptakan proses pendidikan yang berkualitas. Apabila ini berhasil secara tidak langsung akan berdampak pada produktivitas lembaga pendidikan Islam dalam menghasilkan manusia (lulusan) yang berkualitas, yang pada akhirnya hal tersebut tentu akan dapat mengangkat nama baik lembaga pendidikan Islam di mata masyarakat luas

\section{KESIMPULAN}

Berdasarkan paparan di atas dapat simpulkan bahwa keberadaan manusia (anggota organisasi)-khususnya dalam lembaga pendidikan Islam-adalah hal yang utama, bila dibandingkan dengan sumber daya organisasi lainnya, macam sarana prasarana, dana, maupun kurikulum. Secanggih apapun teknologi yang digunakan, peran dan fungsi manusia tidak dapat digantikan seutuhnya. Manusia adalah sebagai perencana, 70 BIOTA: Jurnal Tadris IPA Biologi FITK IAIN Mataram 
pelaksana, pengendali, pengontrol, pengevaluasi, dan pengembang segala program organisasi. Karenanya, intensitas keberhasilan organisasi tergantung pada kreativitas manusia yang ada dalam organisasi itu sendiri. Guna mengoptimalkan peran dan fungsi manusia dalam organisasi, diperlukan usaha penggerakan (motivating) yang optimal dengan memanfaatkan segala teknik yang ada di dalamnya agar mereka mau dan ikhlas bekerja. Khusus dalam lembaga pendidikan Islam, menggerakkan anggota organisasi dengan cara menghidupkan semangat ibadah kepada Allah SWT sebagai landasan kerja merupakan teknik paling ampuh di tengah kondisi lembaga pendidikan Islam-khususnya yang swasta-yang sebagian besar serba kekurangan.

\section{DAFTAR PUSTAKA}

Amirullah dan Rindyah Hanafi. 2002. Pengantar Manajemen. Yogyakarta: Graha Ilmu

Bafadal, Ibrahim. 2004. Peningkatan Profesionalisme Guru Sekolah Dasar dalam Kerangka Manajemen Peningkatan Mutu Berbasis Sekolah. Jakarta: PT Bumi Aksara

Daulay, Haidar Putra. 2004. Pendidikan Islam dalam Sistem Pendidikan Nasional di Indonesia. Jakarta: Prenada Media

Depag. RI. 2005. Al-Qur'an dan Terjemahannya. Bandung: CV Penerbit Jumanatul 'Ali Art

Efendi, Ek. Mochtar. 1986. Manajemen; Suatu Pendekatan Berdasarkan Ajaran Islam. Jakarta: Bhratara Karya Aksara

Fathoni, Abdurrahmat. 2006. Manajemen Sumber Daya Manusia. Jakarta: PT Rineka Cipta

Hasibuan, Malayu S.P. 2005. Manajemen Sumber Daya Manusia. Jakarta: PT Bumi Aksara

Hasibuan, Malayu S.P. 2006. Manajemen; Dasar, Pengertian dan Masalah. Jakarta: PT Bumi Aksara

Kennedy, Carrol. 1999. Managing with Gurus; Mengelola Bersama Para Guru. Terj. Soesanto Boedidarmo. Jakarta: PT Elex Media Komputindo 
Mulyasa, E. 2003. Menjadi Kepala Sekolah Profesional: dalam Konteks Menyukseskan MBS dan KBK. Bandung: PT. Remaja Rosdakarya

Ranupandojo, Heidjrachman. 1996. Dasar-Dasar Manajemen. Yogyakarta: UPP-AMP YKPN

Siagian, Sondang P. 2005. Filsafat Administrasi. Jakarta: PT Bumi Aksara

Siagian, Sondang P. 2005. Fungsi-Fungsi Manajerial. Jakarta: PT Bumi Aksara

Soebahar, Abdul Halim. 2002. Wawasan Baru Pendidikan Islam. Jakarta: Kalam Mulia

Sudjana, D. 2004. Manajemen Program Pendidikan untuk Pendidikan Nonformal dan Pengem-bangan Sumber Daya Manusia. Bandung: Falah Production

Sukarna. 2000. Dasar-Dasar Manajemen. Bandung: CV Mandar Maju.

Suprayogo, Imam. 2006. Buku Pedoman Mata Kuliah Manajemen Sumber Daya Manusia. Malang: UIN Malang

Suwarno, Wiji. 2006. Dasar-Dasar Ilmu Pendidikan. Yogyakarta: Ar-Ruzz Media

Tanthowi, Jawahir. 1983. Unsur-Unsur Manajemen Menurut Ajaran Al-Qur'an. Jakarta: Pustaka Al-Husna

Usa, Muslih (Ed.). 2000. Pendidikan Agama Islam di Indonesia. Yogyakarta: PT Tiara Wacana Yogya

72 BIOTA: Jurnal Tadris IPA Biologi FITK IAIN Mataram 